\title{
Clock genes as a link between addiction and obesity
}

European Journal of Human Genetics (2006) 14, 5. doi:10.1038/sj.ejhg.5201524; published online 16 November 2005

In their recent News and Commentary article, Yuferov et $a l^{1}$ reviewed the evidence for a role of clock genes in modulating drug addiction. They focused on findings in Clock mutant mice. ${ }^{2}$ These mice do not have a functional CLOCK protein (a transcription factor that may regulate the expression of genes with E-box sequences in their promoters) and they express increased reward behaviors in response to cocaine. However, another important phenotype of Clock mutant mice, which may be relevant for drug addiction has not been mentioned. These mice also suffer from obesity and have a serious metabolic syndrome. ${ }^{3}$ It has already been inferred that obesity and addiction may share common mechanisms. The fact that Clock mutant mice are models for both addiction and obesity may be interpreted as evidence that clock genes participate in brain mechanisms that regulate eating and cocaine addiction (eg, pleasure); for example, through a dopamine neurotransmitter system. ${ }^{2}$ However, an alternative explanation may be that the peripheral action of clock genes, for example on adipose cells, is the common mechanism. Shimba $e t \mathrm{l}^{4}$ reported that another clock gene product, BMAL1, which acts in concert with CLOCK as a transcription factor, directly regulates lipogenesis. Alterations in the metabolism of fatty acids may significantly modulate the behavioral effects of cocaine. ${ }^{5}$ Since fat metabolism and fatty acids may prominently influence neuronal functioning, it is possible that Clock mutants have an altered cocaine responsiveness, due to both the central and peripheral sites of clock genes action.

\author{
Hari Manev ${ }^{*, 1}$ and Tolga $\mathrm{Uz}^{1}$ \\ ${ }^{1}$ Department of Psychiatry, The Psychiatric Institute, \\ University of Illinois at Chicago, \\ Chicago, IL 60612, USA \\ *Correspondence: Professor H Manev, \\ The Psychiatric Institute, \\ Department of Psychiatry, \\ University of Illinois at Chicago, \\ 1601 West Taylor Street, MC912, \\ Chicago, IL 60612, USA. \\ Tel: + 312413 4558; Fax: + 312413 4569; \\ E-mail:Hmanev@psych.uic.edu
}

\section{References}

1 Yuferov V, Butelman ER, Kreek MJ: Biological clock: Biological clocks may modulate drug addiction. Eur J Hum Genet 2005; 13: 1101-1103.

2 McClung CA, Sidiropoulou K, Vitaterna $\mathrm{M}$ et al: Regulation of dopaminergic transmission and cocaine reward by the Clock gene. Proc Natl Acad Sci USA 2005; 102: 9377-9381.

3 Turek FW, Joshu C, Kohsaka A et al: Obesity and metabolic syndrome in circadian Clock mutant mice. Science 2005; 308: 1043-1045.

4 Shimba S, Ishii N, Ohta Y et al: Brain and muscle Arnt-like protein1 (BMAL1), a component of the molecular clock, regulates adipogenesis. Proc Natl Acad Sci USA 2005; 102: 12071-12076.

5 Kurtuncu M, Battista N, Uz T et al: 5-Lipoxygenase gene disruption in mice alters their behavior, cocaine responsiveness, and the brain endocannabinoid system. Program No. 800.6, 2005 Abstract Viewer/Itinerary Planner. Washington, DC: Society for Neuroscience, Online. 